\title{
Faktör V Leiden ve MTHFR İkili Mutasyonu Bulunan Renal Ven Trombozlu Yenidoğan Olgusu
}

\section{A Newborn Case With Renal Vein Thrombosis Due to Double Mutations of Factor V Leiden and MTHFR}

\author{
Hakan Altın ${ }^{1}$, Şenol Çitli ${ }^{1}$, Ahmet Akçay ${ }^{1}$
}

${ }^{1}$ Kanuni Eğitim ve

Araştırma Hastanesi, Çocuk

Kardiyoloji Birimi

\section{Corresponding Author:}

Dr. Hakan Altın

\section{Address: \\ Kanuni Eğitim ve Araştırma Hastanesi, Çocuk \\ Kardiyoloji Birimi}

Tel: 046234156 56-1146566

\section{E-mail:}

dr.hakanaltin@hotmail.com

\section{Başvuru Tarihi/Received :} 11-07-2014

Kabul Tarihi/Accepted: 03-09-2014

\section{ÖZET}

Yenidoğan bebeklerde eriskinlere göre antikoagulan ve fibrinolitik sistem protein düzeylerinin daha düşük olması nedeniyle tromboza yatkınlık mevcuttur. Hipoksi, enfeksiyon, dehidratasyon, polisitemi, diyabetik anne bebeği, damar içi kateter kullanımı ve protrombotik genetik bozukluklar gibi hazırlayıcı faktörlerin varlığında tromboz sıklığı artmaktadır. Renal ven trombozu ciddi sağlık problemlerine yol açabilir ve klinik olarak hematüri, böbrek yetmezliği, trombositopeni, hipertansiyon, oligüri ve palpasyon ile batında ele gelen kitle seklinde ortaya çıkar. Renal ven trombozu yenidoğan döneminde oldukça nadir olarak görülmesine rağmen son y1llarda sıklı̆̆ 1 giderek artmaktadır. Bu makalede Faktor V Leiden ve Metilentetrahidrofolat reduktaz (MTHFR) mutasyonlarının genetik predispozisyonunda mekonyum aspirasyon sendromu ve renal ven trombozu gelişen bir yenidoğan olgusu sunulmuştur.

Anahtar Kelimeler: Yenidoğan, Renal Ven Trombozu, Gen Mutasyonu

\section{ABSTRACT}

Newborns are more susceptible to thrombosis than adults due to their lower amount of anticoagulant and fibrinolytic system proteins. Incidence of thrombosis rises with presence of the predisposing factors such as hypoxia , infection, dehydration, polycytemia, infants of diabetic mothers, intravenous catheter use, and prothrombotic genetic disorders. Renal vein thrombosis can lead to potentially serious health problems and clinically present with hematuria, renal failure, thrombocytopenia, hypertension, oliguria and palpable mass in the abdomen. Although renal vein thrombosis is a rare disease of newborn its incidence has been increased in recent years. In this article we presented a newborn case with meconium aspiration syndrome and renal vein thrombosis with presence of the genetic predisposing factors as Factor $\mathrm{V}$ Leiden and MTHFR gene mutations.

Key words: New Born, Renal Vein Thrombosis, Gene Mutation 


\section{GíRiş}

Yenidoğan döneminde semptomatik tromboz 10.000 canlı doğumda 0.51 olarak bildirilmiştir (1). Günümüzde ileri derecede prematüre bebeklerin sayılarının artması, teknik ve tıbbi imkanların ilerleyerek klinik olarak ağır hasta olan bebeklerin uzun süre yaşatılabilmeleri ve kateterizasyon benzeri girişimlerin çoğalması nedeniyle yenidoğan yoğun bakım ünitelerinde bu oran y1lda 2.4/1000'e kadar yükselmiştir (2). Yenidoğan dönemindeki trombozların yarısını venöz, diğer yarısını arteriyel trombozlar oluşturmaktadır. Kateter ile ilişkili olmayan venöz trombozların içinde en sık görüleni renal ven trombozudur (RVT) ve tüm yenidoğan trombozlarının \% 10'unu oluşturmaktadır (2). Yenidoğan RVT'nun başlangıç mekanizması kesin olarak belli değildir ancak hipervizközite, hipoksi, dehidratasyon gibi durumlarda renal kan akımının azaldığı ve bu koşulların trombüs oluşumuna zemin hazırladığı bilinmektedir. Ayrıca son yıllarda tromboemboliye yatkınlık oluşturabilecek çeşitli genetik bozukluklar tanımlanmıştır (3).

$\mathrm{Bu}$ makalede yenidoğan yoğun bakım ünitesine mekonyum aspirasyon sendromu (MAS) ve hipoksik doğum tanılarıyla yatırılan ve takibinde RVT gelişen, etiyolojiye yönelik yapılan incelemelerde de faktör $\mathrm{V}$ Leiden ve metilentetrahidrofolat redüktaz (MTHFR) 1298 ikili mutasyonu tespit edilen bir olgu sunulmaktadır.

\section{OLGU}

Prenatal olarak özelliği olmayan ve anne babası arasında akrabalık bulunmayan erkek bebek, 26 yaşındaki annenin ilk gebeliğinden 38 . gestasyonel haftada nonstres testinde fetal bradikardi görülmesi üzerine acil sezaryen ile doğurtuldu. Yoğun mekonyum ile kaplı olduğu için derin trakeal aspirasyon uygulandı. Apgar skoru birinci dakika 5 ve 5 . dakika 7 olarak değerlendirilen hasta yarım saatin sonunda solunum sıkıntısının artması üzerine entübe edilerek yoğun bakım ünitesine yatırıldı. Ampirik olarak ampisilin ve amikasin başlanıldı. Hastamızın ilk gün yapılan laboratuvar tetkiklerinde: Hemoglobin $12 \mathrm{~g} / \mathrm{dl}$, hematokrit \% 38, lökosit sayıs1 19600/mm3, trombosit sayıs1 120000/mm3, kan şekeri $78 \mathrm{mg} / \mathrm{dl}$, üre $16 \mathrm{mg} / \mathrm{dl}$, kreatin $0.8 \mathrm{mg} / \mathrm{dl}, \quad$ CRP $2 \mathrm{mg} / \mathrm{L}$, akciğer grafisinde her iki akciğerde infiltrasyonlar tespit edildi.

Hastanın yatışının 2. günü göz kapaklarında ve ekstremitelerde yaygın ödem, idrar çıkımında azalma, tartı alımında artış ve hipertansiyon (105 mmhg sistolik kan basinc1) gelişti. Batının sağ tarafında palpasyon ile 4-5 $\mathrm{cm}$ kitle saptandi. Tetkiklerinde makroskobik hematüri, kreatin $1.9 \mathrm{mg} / \mathrm{dl}$, albümin $2.5 \mathrm{~g} / \mathrm{dl}$, trombosit say1s1 $95000 / \mathrm{mm} 3$, hemoglobin 10.8 g/dl, lökosit sayıs1 16000/mm3, CRP $2.5 \mathrm{mg} / \mathrm{L}$ tespit edildi. $\mathrm{Bu}$ bulgularla hastada RVT düşünüldü. Batın ultrasonografisinde her iki böbrekte ekojenite artış1 ve globuler genişleme, sağ ana renal vende trombüs görüldü. Sol küçük renal arterlerde şüpheli trombüsler izlendi. İnferior vena cava'da (IVC) trombüs saptanmadi. Doppler ultrasonografi incelemesinde sağ ana renal vende akım görülemedi, sol ana renal venin akımı normaldi. Kreatin değerlerinde yükselme olduğundan ve sol böbrekteki trombüsün kesin olarak ekarte edilememesi nedeniyle olgumuza düşük molekül ağırlıklı heparin tedavisi başlanıldı.

Hastanın yatışının 3. günü solunum sıkıntısı azaldı ve ekstübe edildi, makroskobik hematüri ve oligüri düzeldi. Yatışının 5. günü hematüri ve ödemi tamamiyle kayboldu, kan basıncı normal değerlere geriledi; laboratuvar tetkiklerinde kreatin $2.5 \mathrm{mg} / \mathrm{dl}$, trombosit sayıs 188000/mm3, hemoglobin $11.4 \mathrm{~g} / \mathrm{dl}$ olarak saptandi. Ultrasonografi incelemesinde sağ ana renal vende trombüsün rekanalize olduğu izlendi. Hastanın yatışının 15. gününde yapılan ultrasonografi incelemesinde sağ ana renal vende trombüs görülmedi, kreatin değeri 1.1 mg/dl' ye kadar geriledi. Düşük molekül ağırlıklı heparin tedavisi ile taburcu edildi. Klinik olarak yakın takip edilen hastaya 3 . ay sonunda yapılan 


\section{DOI: $10.16899 /$ ctd. 88818}

tetkiklerde trombüsün olmadığı, sağ böbreğin fonksiyonunu kaybettiği ve atrofiye gittiği görüldü; kreatin $0.8 \mathrm{mg} / \mathrm{dl}$ idi ve hipertansiyon bulunmamaktayd1.

Hastamızda tromboemboliye yatkınlık açısından yapılan tetkiklerde heterozigot faktör V Leiden ve homozigot metilentetrahidrofolat redüktaz 1298 (MTHFR) ikili mutasyonu tespit edildi. Aileye genetik danışma verildi.

\section{TARTIŞMA}

Yenidoğanların kendilerine özgü fizyolojilerinden dolayı tromboemboliye yatkınlıkları bulunmaktadır. Yüksek hematokrit seviyesi ve buna bağlı hipervizkozite, koagulasyon ve retiküloendoteliyal sistemin tam olarak gelişmemesi (Antitrombin 3, Protein C, Protein S, Plazminojen ve Doku Plazminojen Aktivatörü seviyelerinin düşüklüğ̈̈) en önemli etkenler gibi görünmektedir. Bazı genetik protrombotik risk faktörlerinin (Antitrombin, Protein $\mathrm{C}$ ve $\mathrm{S}$ eksikliği, aktif Protein $\mathrm{C}$ direnci (faktör V G1691A mutasyonu var veya yok iken), Protrombin gen G 20210 A mutasyonu, disfibrinojenemi, faktör VIII yüksekliği, hiperhomosisteinemi ve Lipoprotein (a) yüksekliği) varlığı da venöz ve arteriyel tromboemboli gelişme riskini arttırmaktadır (46). Fizyolojik olarak tromboemboliye yatkınlık olduğu bilinen yenidoğan döneminde; bununla birlikte asfiksi, diyabetik anne bebeği, polisitemi, enfeksiyon, kateter uygulamaları, konjenital kalp hastalıkları, dehidratasyon, nekrotizan enterokolit, RDS gibi ilave sorunların bulunmas1 durumunda tromboembolik olay olma ihtimali oldukça artmaktadır (7). Bizim olgumuzda MAS ve hipoksik doğum gibi risk faktörlerinin yanı sira heterozigot Faktör V Leiden ve homozigot MTHFR 1298 mutasyonları mevcuttu. Son yıllarda literatüre baktığımızda yenidoğan RVT ile özellikle Faktör V Leiden ve MTHFR gen mutasyonlarının birlikte görüldüğ̈̈ olguların bildirilmesi dikkat çekici olarak görülmektedir $(8,9)$. Genetik mutasyonların ve trombozların ilişkisinin tam olarak ortaya konulabilmesi için geniş çaplı epidemiyolojik çalışmalara ihtiyaç bulunmaktadır.

Yenidoğan döneminde görülen spontan tromboemboli olgularının arasında en sık görüleni RVT'dur. Klinik ve laboratuvar olarak makroskobik hematüri, proteinüri, batın palpasyonunda kitle ele gelmesi, böbrek yetmezliği, trombositopeni ve hipertansiyon bulgularıyla ortaya çıkar $(10,11)$. Hastamızda makroskobik hematüri, batın sağ tarafinda palpasyon ile ele gelen kitle, hafif derecede trombositopeni, hipertansiyon ve hafif düzeyde böbrek yetmezliği bulunmaktaydı.

Renal ven trombozu bulunan olgularda trombüs küçük venlerde başlar ve sonrasında ana renal vene ulaşır; \% 52-60 oranında IVC'ya uzanabilir. Olguların \% 25'i her iki böbreği etkiler ve \% 15 'inde ek olarak adrenal kanama eşlik edebilir (12). Ultrasonografi incelemesinde erken dönemde böbrekte globüler genişleme, ekojenitede artma, kortiko-meduller sinırın silinmesi ve normal sinus ekojenitesinin kayb1 görülebilir. Renal vende ve IVC'da trombüs saptanabilir. Doppler inceleme ile renal vende akımın olmaması RVT tanısının konulması için oldukça değerlidir (12). Hastamızın yatışının 2. gün yapılan ultrasonografi incelemesinde her iki böbrekte ekojenite artışı ve globuler genişleme mevcuttu. Sağ ana renal vende trombüs saptand1, IVC'da trombüs görülmedi, sol böbreğin küçük venlerinde şüpheli trombüs görünümü tespit edildi. Doppler incelemede sağ ana renal vende akım alınamazken sol renal vende akım normaldi.

Yenidoğanların kendilerine özgü fizyolojilerinin bulunması ve uygulanacak trombolitik ve antikoagulan tedavilerin kanama gibi olas1 yan etkileri nedeniyle RVT bulunan olguların tedavileri konusunda fikir birliği bulunmamaktadır. Yenidoğan dönemindeki RVT olgularında mümkünse tedavinin deneyimli pediyatrik hematolog, neonatolog ve pediyatrik cerrahın bulunduğu bir merkezde yapılmas1 önerilmektedir. Tedavide sıv1 elektrolit dengesinin sağlanması, enfeksiyon tedavisi ve altta yatan tetikleyici etkenlerin ortadan kaldırılması gibi destekleyici 


\section{DOI: $10.16899 /$ ctd. 88818}

yaklaşımlar oldukça önem taşımaktadır. Temel olarak trombüsün büyümesinin engellenmesi (antitrombotik) ve eritilmesi (trombolitik) amaçlanmaktadır. $\mathrm{Bu}$ amaçla streptokinaz, ürokinaz, doku plazminojen aktivatörü gibi sistemik trombolitik tedavilerin yanı sıra standart heparin ve düşük molekül ağırlıklı heparin gibi antitrombotik tedaviler de uygulanabilmektedir. Trombolitik ajanlar kanama riskini oldukça arttırdığı için sadece yaşam1, organı veya ekstremiteyi tehdit eden seçilmiş olgularda kullanılmaktadır. Yakın zamanda cerrahi müdahele geçirmiş, intrakraniyel veya başka bir bölgede kanaması bulunan, trombositopenisi olan ve koagulasyon testlerinde kanamaya yatkınlık saptanan yüksek riskli olgularda trombolitik tedavi verilmesi uygun değildir. Düşük molekül ağırlıklı heparin tedavisi monitorizasyon sıklığının az olması, diğer ilaçlar ve gıdalar ile etkileşiminin bulunmaması, standart heparinin neden olduğu trombositopeni için daha az risk taşıması ve subkutan uygulanabilmesi gibi avantajları nedeniyle yenidoğan RVT olgularında son yıllarda sık olarak tercih edilmeye başlanmıştır.

Böbrek yetmezliğinin eşlik ettiği bilateral RVT olgularında trombolitik ve antikoagulan tedavinin birlikte, mümkünse ilk 24 saatte verilmesi önerilmektedir. İnferior vena cavaya uzanmayan ve böbrek yetmezliği eşlik etmeyen tek taraflı RVT olguları antikoagulan tedavi verilmeden destekleyici tedavi ile takip edilebilir. İnferior vena cavaya yayılan tek taraflı RVT olgularında ise 3 ay süre ile düşük molekül ağırlıklı heparin tedavisi uygulanabilir (13-14). Kanada'da RVT bulunan 23 olgu üzerinde yapılan bir çalışmada; uzun dönemde böbrek fonksiyon bozukluğu heparin alan olgularda \% 33, almayanlarda ise \% 100 olarak saptanmış ve hiçbir hastanın diyaliz ihtiyacı olmadığı bildirilmiştir (11). Yapılan bir çalışmada tek taraflı RVT olgularının antikoagulan tedavi almadan spontan olarak iyileştiği; bu olgulara antikoagulan ve/veya fibrinolitik tedavi verilmesinin renal sonuçları olumsuz etkilediği ve olası intrakraniyel ve adrenal kanama gibi yan etkileri nedeniyle akut dönemde hayatı tehdit edebilen sonuçlara neden olabildiği bildirilmiştir (15). Tek taraflı RVT olguları sıklıkla intrauterin dönemde ve doğum esnasında oluşur, klinik olarak hemen bulgu vermez ve bu nedenle tedavi uygulanması gecikir. Buna karşın bilateral RVT olgularında ise hemen bulgu verdikleri için fibrinolitik tedavi erken dönemde başlanabilir. $\mathrm{Bu}$ nedenle trombolitik tedavi bilateral RVT olgularında tek taraflı RVT olgularına göre daha etkili gibi gözükmektedir (15). Kullanılacak ilaçların seçimi, dozları, kullanım süreleri ve yan etkileri ile bu ilaçların uzun dönem prognoza etkisi konusunda geniş katılımlı prospektif çalışmalara ihtiyaç bulunmaktadır. Bizim olgumuzda hafif düzeyde böbrek yetmezliği mevcuttu, trombüs sağ ana renal vende görülüp IVC'ya uzanmamıştı. Her iki böbrekte ekojenite artışı, globüler genişleme ve sol böbreğin küçük venlerinde şüpheli trombüs izlenmişti, dolayısı ile sol böbrekteki tutulum varlığ 1 ekarte edilemedi. Bu nedenle hastamıza düşük molekül ağırlıklı heparin tedavisi başland. Tedavinin 5. günü ultrasonografide trombüs kayboldu ve sağ ana renal vende akımın başladığı görüldü. Olguya 3 ay süresince heparin verildi, tekrar edilen ultrasonografi tetkiklerinde trombüs izlenmedi. Renal ven trombozu bulunan yenidoğanların \% 3'ünün akut dönemde kaybedildiği, uzun dönem takiplerde ise $\% 70$ oranında etkilenen böbreğin atrofiye gittiği, \% 20 olguda hipertansiyon görüldüğü ve \% 3 olguda da kronik böbrek yetmezliği geliştiği rapor edilmiştir $(3,12)$. Hastamızda akut dönem haricinde (ilk 5 gün) hipertansiyon saptanmadı, kreatin değerleri 1. ayda normale döndü, 3. ay sonunda yapılan tetkiklerde sağ böbreğin fonksiyon görmediği ve boyutlarının küçülerek atrofiye gittiği tespit edildi.

Yenidoğan RVT olgularında hastalığın akut döneminde ölümler görülebilmekte ve kronik dönemde de hipertansiyon, böbrek atrofisi ve kronik böbrek yetmezliği gibi oldukça ciddi sağlık sorunları ortaya çıkabilmektedir. Bu nedenle genetik predispozisyon çok iyi belirlenmeli; klinik olarak tromboemboliye yatkınlık açısından risk taşıyan yenidoğanlarda 
Journal of Contemporary Medicine 2015;5(2): 135-39

Altin et al.

DOI: $10.16899 /$ ctd. 88818

koagulasyon testleri ve genetik çalışmalar hızla yapılmalı ve bir an önce antitrombotik ve/veya trombolitik tedavi başlanmalıdır. Ayrıca hastanın ailesine uygun genetik danışma verilmelidir.

\section{KAYNAKLAR}

1. Nowak-Gottl U, von Kries R, Gobel U. Neonatal symptomatic thromboembolism in Germany: Two year survey. Arch Dis Child Fetal Neonatal Ed 1997;76:163-7.

2. Schmidt B, Andrew M. Neonatal thrombosis: Report of a prospective Canadian and international registry. Pediatrics 1995;96(5 Pt 1):939-43.

3. Lau KK, Stoffman JM, Williams S, McCusker P, Brandao L, Patel S, et al. Canadian Pediatric Thrombosis and Hemostasis Network. Neonatal renal vein thrombosis: review of the English-language literatue between 1992 and 2006. Pediatrics 2007; 120:1278-84

4. Manco-Johnson M, Nuss R. Neonatal thrombotic disorders. Neoreviews 2000;10:201-4.

5. Tanindi S, Kurekci AE, Koseoglu V, Kurt M, Ozcan O The normalization period of platelet aggregation in newborns. Thromb Res 1995;80:57-62.

6. Andrew M, Paes B, Milner R, Johnston M, Mitchell L, Tollefsen DM, et al. Development of the human coagulation system in the full-term infant. Blood 1987;70(1):165-72

7. Lynch JK. Epidemiology and classification of perinatal stroke. Semin Fetal Neonatal Med 2009;14:245-9.

8. Muwakkit SA, Saab R, Sanjad SA, Bhar SI, Ishak RS, Samad ZA, et al. Renal venous thrombosis in a newborn with prothrombotic risk factors. Blood Coagul Fibrinolysis. 2009;20(6):458-60.

9. Wannes S, Soua H, Ghanmi S, Braham H, Hassine M, Hamza RA, et al. Neonatal renal vein thrombosis in heterozygous carrier of both factor $\mathrm{V}$ Leiden and the MTHFR gene mutation. Arch Pediatr 2012;19(4):419-21.

10. Kosch A, Kuwertz-Broking E, Heler C, Kurnik K, Schobess R, Nowak-Gottl U. Renal venous thrombosis in neonates: Prothrombotic risk factors and long-term follow-up. Blood 2004;104:1356-60.

11. Zigman A, Yazbeck S, Emil S, Nguyen L. Renal vein thrombosis: a 10-year review. J Pediatr Surg 2000;35:1540-2.

12. Brandao LR, Simpson AE, Lau KK. Neonatal renal vein thrombosis. Semin Fetal Neonatal Med 2011;16:323-8.

13. Monagle $\mathrm{P}$, Chan AK, Goldenberq NA, Ichord RN, Journeycake JM, Nowak-Göttl U, et al. Antithrombotic therapy in neonates and children: Antithrombotic Therapy and Prevention of Thrombosis, 9th ed: American College of Chest Physicians Evidence-Based Clinical Practive Guidelines. Chest 2012;141(2 Suppl):737-801.

14. Messinger Y, Sheaffer JW, Mrozek J, Smith CM, Sinaiko AR. Renal outcome of neonatal renal venous thrombosis: review of 28 patients and effectiveness of fibrinolytics and heparin in 10 patients. Pediatrics 2006;118:1478-84.

15. Monagle $\mathrm{P}$, Chan A, Massicotte $\mathrm{P}$, Chalmers $\mathrm{E}$ Michelson AD. Antithrombotic therapy in children: the Seventh ACCP Conference on Antithrombotic and Thrombolytic Therapy. Chest 2004; 126(Suppl): 645-87. 